\title{
A novel splicing mutation in the SLC9A3R1 gene in tumors from ovarian cancer patients
}

\author{
ERICA LORENA KREIMANN ${ }^{1}$, MAGDALENA RATAJSKA ${ }^{2}$, ALINA KUZNIACKA ${ }^{2}$, \\ BRENDA DEMACOPULO ${ }^{1}$, MACIEJ STUKAN ${ }^{3}$ and JANUSZ LIMON ${ }^{2}$
}

\author{
${ }^{1}$ Department of Radiobiology, National Atomic Energy Commission of Argentina, San Martín, Buenos Aires B1650KNA, \\ Argentina; ${ }^{2}$ Department of Biology and Genetics, Medical University of Gdansk, Gdansk 80211; \\ ${ }^{3}$ Department of Gynecological Oncology, Gdynia Oncology Centre, Powstania Styczniowego, Gdynia 81519, Poland
}

Received December 2, 2014; Accepted August 25, 2015

DOI: $10.3892 / 01.2015 .3796$

\begin{abstract}
The aim of the present study was to investigate novel molecular markers that could improve the diagnosis of ovarian cancer patients or be of predictive value. The sequence of the sodium-hydrogen antiporter 3 regulator 1 (SLC9A3R1) gene that codes for the PDZ2 motif of the $\mathrm{Na}^{+} / \mathrm{H}^{+}$exchanger regulatory factor 1 (NHERF1) protein was analyzed. Changes in migration and cell transformation, and alterations of growth factor signaling pathways have been described in cells lacking endogenous NHERF1 or expressing an isoform lacking the function of the PDZ2 domain. Exons 2 and 3, together with flanking intronic sequences of the SLC9A3R1 gene, were amplified and bi-directionally sequenced in 31 primary tumor samples from epithelial ovarian cancer patients. In total, 3 different previously undescribed mutations were detected in 8 out of 31 serous adenocarcinoma tumor samples (25.8\%). Bioinformatics analysis predicted a significant effect in the splicing process as a result of the mutations that could disrupt the NHERF1 PDZ2 domain. Point mutations in consensus splicing recognition are a major cause of the splicing defects that are found in several diseases, including cancer. It has previously been shown that a lack of exon 2 and disruption of the PDZ2 domain contribute to cell transformation and leads to modifications in the physiological regulation of the conformational state of NHERF1. Further studies in bigger groups of ovarian cancer patients will determine the importance of this mutation in disease progression and patient survival.
\end{abstract}

Correspondence to: Dr Erica Lorena Kreimann, Department of Radiobiology, National Atomic Energy Commission of Argentina, 1,499 General Paz Avenue, San Martín, Buenos Aires B1650KNA, Argentina

E-mail:kreimann@cnea.gov.ar; ekreimann@gmail.com

Key words: ovarian cancer, SLC9A3R1 gene, mutation, splicing, PDZ2

\section{Introduction}

Epithelial ovarian cancer (EOC) is the seven most frequent type of cancer in women and the eighth cause of mortality from cancer in women worldwide (1). In contrast to the continuous development in molecular characterization of a number of neoplasms, the progress made in understanding the molecular background of ovarian cancer is limited. This could be due to the complexity of the disease, but also due to certain limitations of study designs and experimental data collection (2).

The sodium-hydrogen antiporter 3 regulator 1 (SLC9A3R1) gene is located on chromosome 17q25.1, consists of six exons and encodes $\mathrm{Na}^{+} / \mathrm{H}^{+}$exchanger regulatory factor 1 (NHERF1). The isolated protein has a molecular weight of $50-53 \mathrm{kD}$, contains 357 amino acids and is structured in three protein domains $(3,4)$. NHERF1 has two PDZ domains (PDZ1 and PDZ2) located in tandem (PSD-95/Dlg/ZO1), mediating protein-protein interaction (5), and a C-terminal ezrin-binding (EB) domain that binds to the ezrin-radixin-moesin (ERM) family of proteins (6).

NHERF1 is expressed primarily at the plasma membrane of polarized epithelia, including that of the kidney, intestine, colon, lungs and uterus. The main function of this adaptor protein is stabilization of protein complexes at the plasma membrane connecting signaling pathways and structural proteins to the cell cytoskeleton (7). NHERF1 binds to $\beta$-catenin through PDZ2, and stabilizes the interaction between $\beta$-catenin and E-cadherin in the adherent junction of epithelial cells $(8,9)$. In the absence of NHERF1, $\beta$-Catenin accumulates in the cytoplasm and E-Cadherin localization at the cell membrane is reduced, resembling the process of epithelial to mesenchymal-like transition (EMT). EMT is observed in normal embryonic development and is recreated during tumor progression (10-12).

NHERF1 has been extensively studied at the protein level, principally in its interactions at the cell membrane, but its gene regulation remains largely unexplored. Thus far, only a few gene mutations associated with human cancer have been characterized. For instance, one previous study (13) in breast cancer showed that the combination of the intragenic mutation rate of 48 breast cancer cell lines and 37 primary breast tumors was $4 \%$. Two missense mutations were described. One of them, a somatic sequence variant of $A A G \rightarrow A A C$ in the NHERF1 PDZ2 
domain that produces a switch in codon 172 (Lys to Asn), was found in primary breast cancer. The other, a missense mutation in codon 180 of exon 2 ( $\mathrm{CGG} \rightarrow \mathrm{TGG}$ ) with a replacement of Arg to Trp, which corresponds to a conserved basic residue in the PDZ2 domain, was found in the MDA-MB-231 breast cancer cell line. Two of the mutations that occur in the PDZ2 domain (codons 172 and 182) decreased the interaction of NHERF1 with SYK (spleen tyrosine kinase), a tumor suppressor gene in the mammary gland. Additionally, the mutation in codon 180 disrupted the interaction with another tumor suppressor gene (Merlin), which shows the importance of the integrity of the PDZ2 motif in NHERF1 tumor suppressor activity in breast cancer (13). A recent study performed by The Cancer Genome Atlas research network analyzed the DNA sequence from coding genes in 316 high-grade serous ovarian adenocarcinomas. No mutations were detected in the coding sequence of the SLCA9AR1 gene despite changes in expression levels and copy number amplification in $7.6 \%$ of the cases; splicing sites were not selected for the analysis (14).

The present study reports the results of mutation analysis in the SLC9A3R1 gene that revealed the presence of splice mutations in 8 out of 31 screened EOC samples (25.8\%). To the best of our knowledge, this is the first study on SLC9A3R1 point mutations in EOC. Further studies in a larger cohort of ovarian cancer patients will determine the predictive and prognostic value of this mutation.

\section{Materials and methods}

Patients and tumor samples. The analysis was performed in 31 EOC tumor adenocarcinoma samples ( 25 high-grade serous, 4 undifferentiated, 1 clear cell and 1 endometrioid sample) from patients who had undergone primary surgery in the Department of Gynecological Oncology, Medical University of Gdansk (Gdansk, Poland) between 1995 and 1996, and between 2002 and 2004. Informed consent was obtained from all patients, and the study was approved by the Medical Review Board of Gdansk Medical University. The patients treated between 1995 and 1996 received 6 cycles of postoperative chemotherapy combination of cisplatin $\left(75 \mathrm{mg} / \mathrm{m}^{2}\right)$ and cyclophosphamide $\left(750 \mathrm{mg} / \mathrm{m}^{2}\right.$ ) every 3 weeks. The patients treated between 2002 and 2004 received 6 cycles of postoperative chemotherapy combination of cisplatin $\left(75 \mathrm{mg} / \mathrm{m}^{2}\right)$ and paclitaxal $175 \mathrm{mg} /$ $\mathrm{m} 2$ (over $3 \mathrm{~h}$ ) every 3 weeks. Only 3 cases did not receive any adjuvant treatment due to a poor performance status (PS 3/4). The disease was classified according to the histological grade (G1-G3) and the International Federation of Gynecology and Obstetrics stage (I-IV) (15). Residual disease was defined by the diameter of the largest tumor left in the abdominal cavity after cytoreductive surgery for advanced stages. Patients with and without a family history of the disease were included in the study. The samples of fresh tumor were immediately frozen at $-80^{\circ} \mathrm{C}$ for molecular analysis; a portion of each tumor was fixed in formalin and embedded in paraffin. Tissue sections $(5 \mu \mathrm{m})$ were obtained from the blocks and stained with hematoxylin and eosin for histopathological analysis.

Molecular screening. The DNA from the ovarian tumors was extracted from fresh tumor tissues by standard phenol-chloroform procedures. The sequences of exons 2 and 3, and the flanking sequences of the SLC9A3R1 gene were amplified with specific primers (13). The sequences were as follows: Exon 2 forward, 5'-AATTGCTGTGTAGGGATCTAG-3' and reverse, 5'-GGAAGAGAGCGAGAAGCATC-3' (322-bp product); and exon 3 forward, 5'ACTGCAAACTGGCTGAGAAC-3' and reverse, 5'-TGGCTCACATCCCTGACTTG-3' (331-bp product). The PCR reaction was carried with the following conditions: $30 \mathrm{ng}$ of DNA/sample in presence of $1.5 \mathrm{mM}$ $\mathrm{MgCl}_{2},\left(95^{\circ} \mathrm{C}\right.$ for $5 \mathrm{sec}$, followed by $95^{\circ} \mathrm{C}$ for $30 \mathrm{sec}$, gradient $56-63^{\circ} \mathrm{C}$ for $30 \mathrm{sec}$ and $72^{\circ} \mathrm{C}$ for $30 \mathrm{sec}$ repeated 34 cycles, and a final amplification step at $72^{\circ} \mathrm{C}$ for $\left.7 \mathrm{~min}\right)$ using the Taq DNA recombinant polymerase (Fermentas, Thermo Scientific, Waltham, MA, USA) according to the manufacturer's instructions. Samples harboring the mutation were re-amplified using high fidelity polymerase (Thermo Scientific) to ensure the result was accurate. Following PCR amplification, the PCR products were cleaned using the Axyprep-96 PCR Cleanup kit following the manufacturer's instruction (Axigen, Corning, Tewksbury, MA, USA). The PCR products were prepare for sequencing using the Big Day reaction. Briefly, the PCR products were amplified with the forward or reverse primers separately according to the manufacturer's instruction. Following the PCR amplification, the product was cleaned using the ExTerminator Nucleotide Terminators Removal kit (A\&A Biotechnology, Gdynia, Poland), according to the manufacturer's instructions, and sequenced directly by bi-directional sequencing (ABI Prism 3130; Applied Biosystems, Life Technologies, Foster City, CA, USA). Electropherograms were analyzed by the free BioEdit Sequence Alignment Editor program (16).

Bioinformatics analyses. To predict the splicing signals in wild-type and mutated DNA sequences, the mutations were analyzed using the bioinformatics Human Splicing Finder (HSF) free program (17). The software allows the comparison of a wild-type and mutant sequence in order to predict the impact of in the splicing process.

\section{Results}

Mutational analysis. Cases characteristics of the 31 patients with EOC included in the study are presented in Table I. The sequences of exons 2 and 3, together with the flanking intronic sequences of the SLC9A3R1 gene that codes for the PDZ2 domain of the NHERF1 protein, were analyzed. In total, 8 out of the 31 analyzed samples $(25.8 \%)$ were found to carry a potentially harmful alteration located in the splicing donor site of intron 2 (Fig. 1; Table II). While 3 samples displayed two different substitutions in the +2 position $(c .603+2 \mathrm{~T}>\mathrm{A}$; c. $603+2 \mathrm{~T}>\mathrm{C}), 5$ other samples exhibited co-occurrence of two substitutions (c. $603+2 \mathrm{~T}>\mathrm{C}$; c. $603+3 \mathrm{G}>\mathrm{A}$ ) located in the same splicing donor site (in the +2 and +3 positions) (Table I). Moreover, reported alterations were only identified in the tumor tissue of the tested cohort of EOC, no alterations were found in the blood of the patients indicating that they were somatic mutations. All identified alterations were located in the consensus sequence of the splice donor site of intron 2 , suggesting a detrimental effect on the splicing process.

Bioinformatics analysis. The mutations were analyzed using the bioinformatics HSF (version 2.4.1), which compares the 
Table I. Characteristic of the 31 patients with epithelial ovarian carcinoma.

\begin{tabular}{|c|c|c|c|c|c|c|c|c|c|}
\hline $\begin{array}{l}\text { Case } \\
\text { no. }\end{array}$ & Tumor & FHOC & $\begin{array}{l}\text { Age, } \\
\text { years }\end{array}$ & $\begin{array}{c}\mathrm{CA}-125, \\
\mathrm{U} / \mathrm{ml}^{\mathrm{a}}\end{array}$ & EOC Histology $\mathrm{y}^{\mathrm{b}}$ & Grade & $\begin{array}{l}\text { FIGO } \\
\text { stage }\end{array}$ & $\begin{array}{c}\text { Residual } \\
\text { disease, } \mathrm{cm}^{\mathrm{c}}\end{array}$ & $\begin{array}{l}\text { OS time, } \\
\text { months }\end{array}$ \\
\hline 1 & 2 & Negative & 63 & $>600$ & Serous & G3 & IIIC & $>5$ & 12.3 \\
\hline 2 & 21 & Negative & 58 & $>600$ & Serous & G1 & IIIC & $>5$ & 10.1 \\
\hline 3 & 23 & Negative & 42 & 1161 & Undifferentiated & G3 & IIIC & $<1$ & 106.7 \\
\hline 4 & 32 & Negative & 74 & 4207 & Serous & G3 & IIIC & $1-5$ & 6.9 \\
\hline 5 & 37 & Positive & 55 & 399 & Serous & G3 & IIIC & $1-5$ & 33.2 \\
\hline 6 & 40 & Negative & 48 & No data & Serous & G1 & IIIC & $<1$ & 7.2 \\
\hline 7 & 49 & Negative & 41 & No data & Serous & $\mathrm{G} 2$ & IIIC & $<1$ & 63.0 \\
\hline 8 & 56 & Positive & 46 & 654 & Serous & G3 & IIIC & $<1$ & 104.3 \\
\hline 9 & 58 & Negative & 77 & No data & Serous & G2 & IIIC & $<1$ & 0.3 \\
\hline 10 & 63 & Negative & 60 & 14 & Serous & G1 & IC & 0 & 32.5 \\
\hline 11 & 74 & Positive & 45 & 599 & Serous & $\mathrm{G} 2$ & IV & $>5$ & 19.6 \\
\hline 12 & 93 & Negative & 75 & 319 & Serous & G3 & IIIC & $1-5$ & 19.9 \\
\hline 13 & 102 & Negative & 32 & 326 & Clear cell & $\mathrm{G} 2$ & IIC & 0 & 130.9 \\
\hline 14 & 118 & Negative & 79 & 7368 & Serous & $\mathrm{G} 2$ & IIIC & $>5$ & 35.0 \\
\hline 15 & 127 & Negative & 47 & 198 & Undifferentiated & G3 & IIIB & $<1$ & 100.4 \\
\hline 16 & 135 & Negative & 55 & $>600$ & Serous & G1 & IIIC & $1-5$ & 16.9 \\
\hline 17 & 137 & Negative & 63 & No data & Serous & G1 & IIIC & $<1$ & 17.8 \\
\hline 18 & 150 & Negative & 56 & 403 & Serous & G3 & IIIC & $<1$ & 0.2 \\
\hline 19 & 153 & Positive & 48 & 1089 & Serous & G3 & IIIC & $<1$ & 87.3 \\
\hline 20 & 157 & Negative & 37 & $>600$ & Serous & $\mathrm{G} 2$ & IIIC & $<1$ & 21.5 \\
\hline 21 & 165 & Negative & 59 & 10 & Serous & G2 & IIIC & $>5$ & 14.6 \\
\hline 22 & 170 & Positive & 78 & No data & Serous & G1 & IIIC & $>5$ & 18.0 \\
\hline 23 & 172 & Negative & 54 & 1001 & Serous & G2 & IIIC & $1-5$ & 94.3 \\
\hline 24 & 182 & Negative & 73 & 563 & Undifferentiated & G3 & IV & $<1$ & 26.6 \\
\hline 25 & 200 & Negative & 73 & 4851 & Serous & G3 & IV & $<1$ & 7.0 \\
\hline 26 & 211 & Positive & 82 & 802 & Serous & G2 & IIIA & $<1$ & 41.7 \\
\hline 27 & 218 & Negative & 88 & No data & Serous & G1 & IV & $<1$ & No FU \\
\hline 28 & 219 & Negative & 54 & 311 & Undifferentiated & G3 & IIIC & $1-5$ & 84.5 \\
\hline 29 & 257 & Negative & 62 & 300 & Serous & $\mathrm{G} 2$ & IIIC & $>5$ & 25.8 \\
\hline 30 & 766 & Positive & 46 & 156 & Endometrioid & G3 & IIB & 0 & 43.3 \\
\hline 31 & 792 & Negative & 36 & 136 & Serous & G1 & IIIB & 0 & 106.9 \\
\hline
\end{tabular}

${ }^{\mathrm{a}} \mathrm{CA} 125$ normal range, $4-41 \mathrm{U} / \mathrm{ml}(29) .{ }^{\mathrm{b}}(15) .{ }^{\mathrm{c}}$ Residual disease, $\mathrm{R}$, is presented as the diameter of the largest tumor left after primary surgery; FHOC, familiar history of ovarian cancer. OS, overall survival; NA, not applicable; CA-125, cancer antigen 125; FIGO, International Federation of Gynecology and Obstetrics; FU, follow-up.

wild-type and mutated sequences to the consensus splice site sequences from the HSF database. The 'consensus splicing site' in the database was determined previously by the analysis of data extracted from Ensembl containing 22,000 genes and 46,000 transcripts of Homo sapiens, which includes introns and exons of all human genes (17). The impact of the mutation is analyzed by using matrices from the study by Shapiro and Senepathy (18) where a consensus value is attributed to each sequence. If the difference between the sequences is $>10 \%$, the program predicts a significant effect in the splicing process. The analysis showed that two of the mutations in the +2 splicing site $($ c. $603+2 \mathrm{~T}>\mathrm{A}$ and c. $603+2 \mathrm{~T}>\mathrm{C})$ could exhibit a significant effect in the splicing process. By contrast, the mutation in the +3 position $(c .603+3 \mathrm{G}>\mathrm{A})$ did not appreciably modify the site (Table III).

\section{Discussion}

The present study analyzed the sequence of exons 2 and 3 of the SLC9A3R1 gene, which encodes the PDZ2 domain of the NHERF1 protein. Through this domain, NHERF1 binds to $\beta$-Catenin and stabilizes the interaction with E-cadherin at cell-cell junctions (9). The PDZ2 domain also has a significant role in the regulation of the conformational state of NHERF1 by an intramolecular interaction with the C-terminal EB region, which is able to mask other protein domains in order to bind to other partner proteins (19).

The present study found two intronic mutations in the donor splicing site of exon 2 of the SLC9A3R1 gene that, to the best of our knowledge, had not been previously described and could affect the expression of the NHERF1 isoforms. Point 
Table II. Mutations in the splicing donor site of the SCLC9A3R1 gene in ovarian cancer.

\begin{tabular}{|c|c|c|c|c|c|c|c|c|c|c|}
\hline $\begin{array}{l}\text { Case } \\
\text { no. }\end{array}$ & Tumor & FHOC & $\begin{array}{c}\text { Age at } \\
\text { diagnosis, } \\
\text { years }\end{array}$ & $\begin{array}{l}\text { CA-125, } \\
\mathrm{U} / \mathrm{ml}^{\mathrm{a}}\end{array}$ & $\begin{array}{c}\text { EOC } \\
\text { histology }\end{array}$ & Grade & $\begin{array}{l}\text { FIGO } \\
\text { stage }\end{array}$ & $\begin{array}{c}\text { Residual } \\
\text { disease, } \mathrm{cm}^{\mathrm{c}}\end{array}$ & $\begin{array}{l}\text { OS time, } \\
\text { months }\end{array}$ & $\begin{array}{l}\text { Splice donor } \\
\text { site mutation in } \\
\text { SLC9A3R1 gene }\end{array}$ \\
\hline 1 & 2 & Negative & 63 & $>600$ & Serous & G3 & IIIC & $>5$ & 12,3 & c. $603+2 \mathrm{~T}>\mathrm{A}$ \\
\hline 2 & 21 & Negative & 58 & $>600$ & Serous & G1 & IIIC & $>5$ & 10,1 & c. $603+2 \mathrm{~T}>\mathrm{C}$ \\
\hline 7 & 49 & Negative & 41 & no data & Serous & G2 & IIIC & $<1$ & 63,0 & c. $603+2 \mathrm{~T}>\mathrm{C}, \mathrm{c} .603+3 \mathrm{G}>\mathrm{A}$ \\
\hline 10 & 63 & Negative & 60 & 14 & Serous & G1 & IC & NA & 32,5 & c. $603+2 \mathrm{~T}>\mathrm{C}, \mathrm{c} .603+3 \mathrm{G}>\mathrm{A}$ \\
\hline 14 & 118 & Negative & 79 & 7368 & Serous & G2 & IIIC & $>5$ & 35,0 & c. $603+2 \mathrm{~T}>\mathrm{C}, \mathrm{c} .603+3 \mathrm{G}>\mathrm{A}$ \\
\hline 15 & 127 & Negative & 47 & 198 & Undifferentiated & G3 & IIIB & $<1$ & 100,4 & c. $603+2 \mathrm{~T}>\mathrm{C}, \mathrm{c} .603+3 \mathrm{G}>\mathrm{A}$ \\
\hline 20 & 157 & Negative & 37 & $>600$ & Serous & G2 & IIIC & $<1$ & 21,5 & c. $603+2 \mathrm{~T}>\mathrm{C}$ \\
\hline 26 & 211 & Positive & 82 & 802 & Serous & G2 & IIIA & $<1$ & 41,7 & c. $603+2 \mathrm{~T}>\mathrm{C}, \mathrm{c} .603+3 \mathrm{G}>\mathrm{A}$ \\
\hline
\end{tabular}

${ }^{\mathrm{a}} \mathrm{CA} 125$ normal range, $4-41 \mathrm{U} / \mathrm{ml}(20) .{ }^{\mathrm{b}}(15)$. ${ }^{\mathrm{R}}$ Residual disease, $\mathrm{R}$, is presented as the diameter of the largest tumor left after primary surgery. NA, not aplicable; SLC9A3R1, sodium-hydrogen antiporter 3 regulator 1; FHOC, familiar history of ovarian cancer; OS, overall survival; CA-125, cancer antigen 125; FIGO, International Federation of Gynecology and Obstetrics.

Table III. Bioinformatics analyses.

\begin{tabular}{|c|c|c|c|c|c|}
\hline \multirow{2}{*}{$\begin{array}{l}\text { No. of } \\
\text { cases }\end{array}$} & \multirow{2}{*}{$\begin{array}{l}\text { Gene SLC9A3R1 } \\
\text { mutations }\end{array}$} & \multicolumn{3}{|c|}{ Human splice finder ${ }^{\mathrm{a}}$} & \multirow[b]{2}{*}{ Software prediction } \\
\hline & & WT CV & Mut CV & $\Delta \mathrm{CV}, \%$ & \\
\hline $7^{\mathrm{c}}$ & c. $603+2 \mathrm{~T}>\mathrm{C}$ & 82.83 & 56 & -32.4 & $\begin{array}{l}\triangle \mathrm{CV} \text { reduction }>10 \%, \\
\text { significant effect in 'splicing' }\end{array}$ \\
\hline $1^{\mathrm{d}}$ & c. $603+2 \mathrm{~T}>\mathrm{A}$ & 82.83 & 56 & -32.4 & $\begin{array}{l}\Delta \mathrm{CV} \text { reduction }>10 \%, \\
\text { significant effect in 'splicing', }\end{array}$ \\
\hline $5^{\mathrm{e}}$ & c. $603+3 \mathrm{G}>\mathrm{A}$ & 82.83 & 83.99 & 1.4 & $\begin{array}{l}\triangle \mathrm{CV} \text { reduction }<10 \%, \\
\text { splicing site not affected }\end{array}$ \\
\hline
\end{tabular}

${ }^{\mathrm{a}}(17) .{ }^{\mathrm{b}} \mathrm{CV}$ to assess the strength of the splicing (16). CV, consensus value; Mut, mutant; WT, wild-type; SLC9A3R1, sodium-hydrogen antiporter 3 regulator $1 .{ }^{\circ}$ Cases $2,7,10,14,15,20$ and $26 .{ }^{\mathrm{d}}$ Case $1 .{ }^{\mathrm{e}}$ Cases $7,10,14,15$ and 26.

A

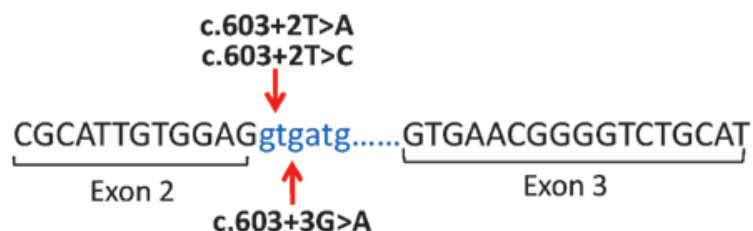

B

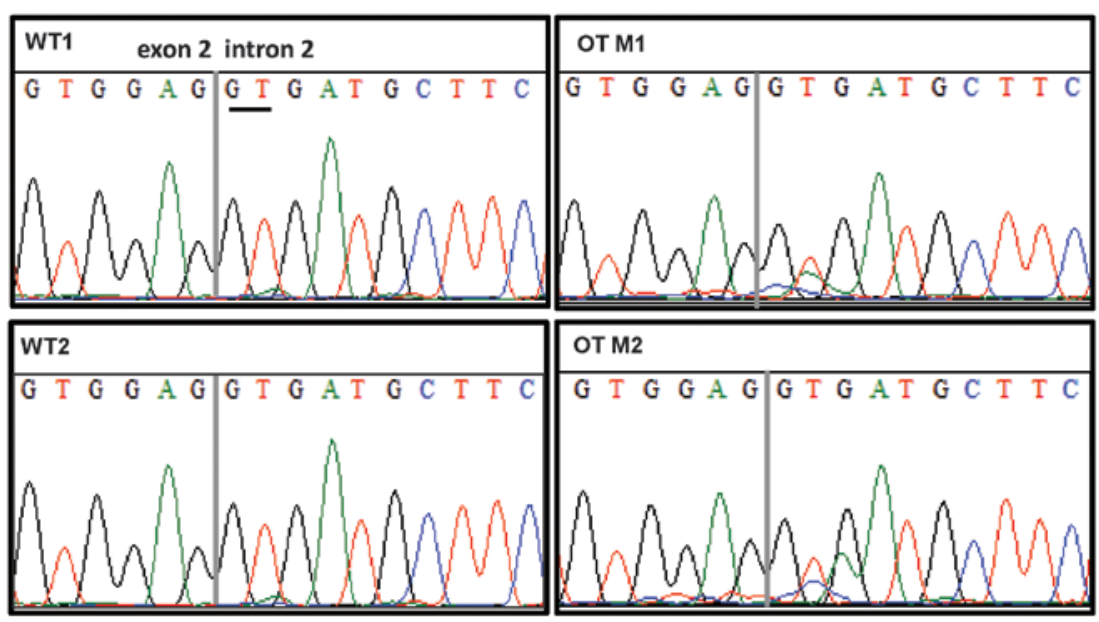

Figure 1. Donor splices site mutations of the sodium-hydrogen antiporter 3 regulator 1 gene in ovarian cancer tumors. (A) Schematic representation of the mutations in the splicing donor consensus sequence (second base of the dinucleotide GT) and the third base of intron 2 found in ovarian tumors. (B) Electropherograms showing the wild type (left), and mutated alleles (c.603+2T $>$ C, c. $603+3 \mathrm{G}>\mathrm{A}$ ) of ovarian tumors (right). 
mutations in splicing recognition sites are a major cause of splicing defects, such as exon skipping of one or more adjacent exons, or inclusion of the intronic sequence, and are frequently found in different diseases (21-25).

It has been reported that the alteration of splicing could have a huge impact during tumorigenesis, as several genes express cancer-specific splicing isoforms (26-28). It was previously shown that one of the tumor suppressor mechanisms displayed by the PDZ2 domain of NHERF1 was the selective stabilization of the interaction between $\beta$-catenin and E-cadherin, which contributes to the maintenance of the structure of polarized epithelial cells. In the absence of NHERF1 expression, the $\beta$-catenin/E-cadherin association is disrupted and leads to decreased $\beta$-catenin at the plasma-membrane localization, reduced expression of E-cadherin at the cell-cell junction and cell transformation $(9,29)$. The potential disruption of the PDZ2 domain as a result of the mutation could modify the interaction of NHERF1 with proteins that interact directly with the PDZ2 domain, such as $\beta$-catenin, as well it possibly affecting the regulation of the conformational state of the protein, and its binding to phosphatase and tensin homolog and ERM proteins (19).

In summary, mutations of splicing recognition sites of the SLC9A3R1 gene in malignant ovarian tumors may potentially affect the behavior of cancer cells. The present study found mutations in early low-grade and advanced (G1-G3) EOC tumors, however, future studies are required in order to understand the clinical implications of these mutations in the prognosis of ovarian cancer patients.

\section{Acknowledgements}

The authors are especially grateful to Dr Alberto R. Kornblihtt for his contribution to the analysis of the results and to Dr Guillermo Juvenal for useful discussions. This study was supported by a grant from the Medical University of Gdansk: ST-2, Polish National Science Centre projects: 2011/02/A/NZ2/00017, the National Research Council of Argentina and the National Agency for the Promotion of Science and Technology of Argentina (PICT 0087, 2008).

\section{References}

1. Ferlay J, Soerjomataram I, Ervik M, Dikshit R, Eser S, Mathers C, Rebelo M, Parkin DM, Forman D and Bray F: GLOBOCAN 2012 v1.0, Cancer Incidence and Mortality Worldwide: IARC CancerBase No. 11 (Internet). International Agency for Research on Cancer,Lyon, France, 2013. http://globocan.iarc.fr. Accessed on Dec 13, 2013.

2. Tinker AV, Boussioutas A and Bowtell DD: The challenges of gene expression microarrays for the study of human cancer. Cancer Cell 9: 333-339, 2006.

3. Weinman EJ, Steplock D, Wang Y and Shenolikar S: Characterization of a protein cofactor that mediates protein kinase A regulation of the renal brush border membrane $\mathrm{Na}(+) / \mathrm{H}+$ exchanger. J Clin Invest 95: 2143-2149, 1995.

4. Reczek D, Berryman M and Bretscher A: Identification of EBP50: A PDZ-containing phosphoprotein that associates with members of the ezrin-radixin-moesin family. J Cell Biol 139: 169-179, 1997
5. Cho KO, Hunt CA and Kennedy MB: The rat brain postsynaptic density fraction contains a homolog of the Drosophila discs-large tumor suppressor protein. Neuron 9: 929-942, 1992.

6. Saotome I, Curto M and McClatchey AI: Ezrin is essential for epithelial organization and villus morphogenesis in the developing intestine. Dev Cell 6: 855-864, 2004.

7. Bretscher A,Chambers D, Nguyen R and Reczek D: ERM-Merlin and EBP50 protein families in plasma membrane organization and function. Annu Rev Cell Dev Biol 16: 113-143, 2000.

8. Shibata T, Chuma M, Kokubu A, Sakamoto M and Hirohashi S: EBP50, a beta-catenin-associating protein, enhances Wnt signaling and is over-expressed in hepatocellular carcinoma. Hepatology 38: 178-186, 2003.

9. Kreimann EL, Morales FC, de Orbeta-Cruz J, Takahashi Y, Adams H, Liu TJ, McCrea PD and Georgescu MM: Cortical stabilization of beta-catenin contributes to NHERF1/EBP50 tumor suppressor function. Oncogene 26: 5290-5299, 2007.

10. Hayashi Y, Molina JR, Hamilton SR and Georgescu MM: NHERF1/EBP50 Is a new marker in colorectal cancer. Neoplasia 12: 1013-1022, 2010.

11. Thiery JP: Epithelial-mesenchymal transitions in tumour progression. Nat Rev Cancer 2: 442-454, 2002.

12. Hazan RB, Qiao R, Keren R, Badano I and Suyama K: Cadherin switch in tumor progression. Ann NY Acad Sci 1014: 155-163, 2004.

13. Dai JL, Wang L, Sahin AA, Broemeling LD, Schutte M and Pan Y: NHERF1 $\left(\mathrm{Na}^{+} / \mathrm{H}^{+}\right.$exchanger regulatory factor) gene mutations in human breast cancer. Oncogene 23: 8681-8687, 2004.

14. Cancer Genome Atlas Research Network: Integrated genomic analyses of ovarian carcinoma. Nature 474: 609-615, 2011.

15. Scully RE: World Health Organization International Histological Classification of Tumours. 2nd edition, Springer, New York, 1999.

16. Hall TA: BioEdit: A user-friendly biological sequence alignment editor and analysis program for Windows 95/98/NT. Nucleic Acids Symp Ser 41: 95-98, 1999.

17. Desmet FO, Hamroun D, Lalande M, Collod-Béroud G, Claustres $\mathrm{M}$ and Béroud C: Human splicing finder: An online bioinformatics tool to predict splicing signals. Nucleic Acids Res 37: e67, 2009.

18. Shapiro MB and Senapathy P: RNA splice junctions of different classes of eukaryotes: Sequence statistics and functional implications in gene expression. Nucleic Acids Res 15: 7155-7174, 1987.

19. Morales FC, Takahashi Y, Momin S, Adams H, Chen X and Georgescu MM: NHERF1/EBP50 head-to-tail intramolecular interaction masks the association with PDZ-domain ligands. Mol Cell Biol 27: 2527-2537, 2007.

20. Pauler DK, Menon U, McIntosh M, Symecko HL, Skates SJ and Jacobs IJ. Factors influencing serum CA125II levels in healthy postmenopausal women. Cancer Epidemiol Biomarkers Prev 10: 489-493, 2001

21. Venables JP: Aberrant and alternative splicing in cancer. Cancer Res 64: 7647-7654, 2004.

22. Cooper DN and Krawczak M: Human Gene Mutation. Bios Scientific Publishers, Oxford, UK, pp111-127, 1993.

23. Cáceres JF and Kornblithtt AR: Alterative splicing: Multiple control mechanisms and involvement in human disease. Trends Genet 18: 186-193, 2002.

24. Baralle D and Baralle M: Splicing in action: Assessing disease causing sequence changes. J Med Genet 42: 737-748, 2005.

25. Fu XD: Towards a splicing code. Cell 119: 736-738, 2004.

26. Blencowe BJ: Alternative splicing: New insights from global analyses. Cell 126: 37-47, 2006.

27. Brinkman BM: Splice variants as cancer biomarkers. Clin Biochem 37: 584-594, 2004.

28. Kalnina Z, Zayakin P, Silina K and Linē A: Alterations of pre-mRNA splicing in cancer. Genes Chromosomes Cancer 42: 342-357, 2005.

29. Nelson WJ and Nusse R: Convergence of Wnt, beta-catenin, and cadherin pathways. Science 303: 1483-1487, 2004. 